\title{
Recruitment dynamics of the tropical rainforest tree Dipteryx oleifera (Fabaceae) in eastern Nicaragua
}

\author{
Javier Ruiz $^{1 *}$, Douglas H. Boucher ${ }^{2}$, Diego Ruiz-Moreno ${ }^{1} \&$ Cherryl Ingram-Flóres ${ }^{3}$ \\ 1. Department of Ecology and Evolutionary Biology. The University of Michigan. Ann Arbor MI 48109, USA; \\ jeruiz@umich.edu; drmoreno@umich.edu \\ 2. Union of Concerned Scientists, 1707 H Street, NW, Suite 600, Washington, DC 20006-3962, USA; \\ dboucher@ucsusa.org \\ 3. Programa Científico Complementario. Barrio Punta Fría. Frente a Imprenta La Salle Costeña. Bluefields, Nicaragua; \\ cheinflor@hotmail.com \\ * Correspondencia.
}

Received 29-V-2008. Corrected 11-VII-2008. Accepted 14-VIII-2008.

\begin{abstract}
Seed production, seed dispersal and recruitment are critical processes in population dynamics, because they are almost never completely successful. We recorded the recruitment dynamics for the population of Dipteryx oleifera in a tropical rainforest in eastern Nicaragua $\left(12^{\circ} 05^{\prime}\right.$ N., $83^{\circ} 55^{\prime}$ W.) from March 2002 to August 2006. Seeds and seedlings had highly clumped distributions, while sapling distributions appeared to be random. Seedling survival increased away from the nearest conspecifc adult tree, where seedling density is lower. Since relative growth rates of seedlings are not correlated with the distance to the nearest conspecific adult, seedling survival appears to be independent of seedling growth. Seedling density is inversely correlated with seedling insect herbivory damage. Seedling survival correlated negatively with the number of saplings per sub-plot (10x10m), suggesting that insect herbivore may also cue in on saplings rather than only on adult $D$. oleifera trees in order to locate seedlings. Seedling establishment is significantly clumped with respect to the nearest adult tree. Larger clumps of seedlings seems more ephemeral than isolated smaller clumps located away from the nearest $D$. oleifera tree. These results support current empirical evidence presented earlier for the Janzen-Connell hypothesis for Dipteryx oleifera at seed and seedling stages and, the Recruitment Limitation hypothesis at the sapling stage, because sapling individuals might have recruited after random light-gap formation. Rev. Biol. Trop. 57 (1-2): 321-338. Epub 2009 June 30.
\end{abstract}

Key words: Dipteryx oleifera, Dipteryx panamensis, recruitment limitation hypothesis, Janzen-Connell hypothesis, seeds, seedlings, saplings, Nicaragua.

Seed production, seed dispersal and recruitment are critically important processes in population dynamics, precisely because they are almost never completely successful (Clark et al. 1999a, Muller-Landau et al. 2002). First, the failure of seeds to arrive at all sites limits population growth rates and abundances, a phenomenon referred to as seed limitation. Consequently, seed limitation has important consequences for population and community dynamics and for species diversity at multiple scales (Tilman 1994, Hurtt and Pacala 1995). Seed limitation can arise from reduced seed production, or from restricted dispersal of available seeds even when seeds are locally abundant. The number of sites that can possibly be reached by seeds depends on the local abundance of adult trees and their fecundity, thus determining the overall [cumulative] seed density (Clark et al. 1998). The variance in seed density depends primarily upon the shapes and sizes of seed shadows, which indicates how seeds are distributed with respect to the nearest conspecific adult (Clark et al. 1998). When adult trees are clumped, as 
they frequently are (Condit et al. 2000), seed limitation will be further increased (Ribbens et al. 1994). Increment in the variance of seed density is often recognizable as seed aggregations through the forest floor.

An important hypothesis concerning recruitment dynamics is that of Janzen (1970) and Connell (1971). The basic prediction here is that plants' natural enemies (i.e. insect herbivores) will respond in a positive densitydependent manner to their host's abundance near the seed source - the adult tree. Escaping from natural enemies is crucial for plant demographic success (Howe and Smallwood 1982). Increased seed dispersal would potentially lower density-dependent effects and, would be responsible for large mean distances between established seedlings and the nearest conspecific adult tree (Condit et al. 1992, Blundell and Peart 1998, Clark et al. 1999b, Hyatt et al. 2003). Consequently, large numbers of tropical tree species might coexist at low densities and with large mean distances between established individuals (Janzen 1970). Evidence at the plant community level was presented in favor of the Janzen-Connell hypothesis in a field study conducted at Barro Colorado Island (BCI) (Condit et al. 1992).

The Janzen-Connell seedling recruitment pattern of the tropical tree species $D$. oleifera is largely determined by insect herbivory damaged (Clark and Clark 1985). In a field study, the level of insect herbivory damage was higher closer to the adult tree where seedling density was high. The spatial pattern of insect herbivory damage and seedling recruitment of $D$. oleifera reported in our research in Nicaragua also provides support in favor of this hypothesis (Ruiz et al. submitted). However, our treatment of the spatial recruitment dynamic process here, adds a novel temporal and spatial component to the evidence about how recruitment occurs in tropical rainforests. Since the effect of insect herbivory on recruitment of larger size stages is less important, if any; the idea has been that microsite conditions, specifically lightconditions above seedlings, saplings and, small juveniles would be positively correlated with crown size, stem size and growth (Clark and Clark 1985). An important finding is that lightgaps formation is independent of the location of the nearest adult tree of D. oleifera (Clark and Clark 1987), which would lead to the recruitment dynamics of larger size stages to be inconsistent with the Janzen-Connell model. Our field observations in the tropical rainforest of Nicaragua suggest that sapling recruitment and small-juvenile recruitment might be correlated with random light-gap formations as also noticed earlier (Clark and Clark 1987).

In specific, this research focuses on determining the recruitment dynamics of the seeds, seedlings and saplings and, to what extent insect herbivory determines the recruitment of D. oleifera in eastern Nicaragua. The specific hypotheses we are testing are: (1) "Seed distribution hypothesis," if dispersal is at random then the per sub-plot variance to mean ratio of the distribution of seeds is not statistically different from a Poisson process; (2) "Seedling recruitment hypothesis," the observed fraction of sub-plots receiving seedling recruitment is less than the one expected under the assumption of random establishment; (3) If seedling insect herbivory damage decreases with the distance to the nearest conspecific adult tree of $D$. oleifera, then seedling survival will be high away from it. In other words, lower insect herbivory damage will be positively correlated with seedling survival away conspecific adults. Complementary to hypothesis 3 is to determine whether seedling relative growth rate decreases as a function of the distance to the nearest conspecific adult tree. If this is the case, then there is evidence suggesting a positive correlation between lower insect herbivory and faster seedling growth rate (hypothesis 4); (5) if seedling mortality is negatively correlated with the number of conspecific saplings, then there is evidence suggesting a positive correlation between natural enemies and the number of saplings per sub-plots. In other words, we propose that insect herbivore might be using saplings to cue in on seedlings. We analyzed each hypothesis using a high-resolution dataset that includes information of the location and 
demography of seeds, seedlings, saplings, and adult individuals in eastern Nicaragua. This dataset expands during 4 years allowing a solid evaluation of the effect of natural enemies on the spatial demography of plant recruitment.

\section{MATERIALS AND METHODS}

Study site: The research was conducted in a tropical rainforest site in eastern Nicaragua $\left(12^{\circ} 05^{\prime}\right.$ N., $83^{\circ} 55^{\prime}$ W.) from March 2002 to August 2006. The site is known as La Unión, and it is accessible by the Caño Negro River. A detailed description of the site was published by Granzow-de-la-Cerda et al. (1997).

Species in study: The study species is D. oleifera also known as D. panamensis, a neotropical canopy emergent tree common in lowland forests. The species produces flowers around May-June, fruits reach maturation in January, February, March or April. The fruit of D. oleifera is large $\sim 6 \times 4 \mathrm{~cm}$ (unpublished data), generally dispersed by bats (i.e. Artibeus jamaicensis, Artibeus literaturs, among others) (Bonaccorso et al. 1980) and rodents (i.e. squirrels, agoutis, pacas, etc.) (Forget and Milleron 1991, Forget 1992, 1993, Cintra and Horna 1997). Bats, disperse seeds from the adult trees by collecting the fruits and discarding these in seed piles below roosting sites (primary dispersal) (Forget and Milleron 1991). Rodents, such as agoutis and squirrels, which could disperse seeds away either from below the canopy of adult conspecific trees or from seed piled up by bats (secondary dispersal) (Fleming and Heithaus 1981). Rodents are classified as either scatter hoarders if they leave seeds scattered individually across the forest floor, or cachehoarders if they congregate seeds in small seed piles (caches), on or buried in the forest floor (Jansen et al. 2006). Moreover, rodent seed dispersal generally occurs when seeds are moved from highly dense areas and then forgotten at locations with lower densities (Forget and Wenny 2005).

Because the wood of $D$. oleifera is very dense, saplings can withstand damage from falling branches (Clark and Clark 1991). D. oleifera can reach a height of about $50 \mathrm{~m}$ and diameter at breast height (DBH) of about 1 $500 \mathrm{~mm}$ (Clark and Clark 1992). Within this research plot there are several individuals with $(\mathrm{DBH})$ greater than $2000 \mathrm{~mm}$.

Methods: A 6.37 ha plot, subdivided into 10x10 m sub-plots was established in 2002 . Yearly censuses of basic demography of each D. oleifera individual have been carried out since that time. Diameters at the base (DB) of the stem were measured for all seedlings and small saplings, where seedlings were those individuals with a height $\leq 1 \mathrm{~m}$, and saplings those with height between 1.01 and $2 \mathrm{~m}$. Height was considered as vertical distance from the forest floor to the highest green tissue. For the purposes of seedling recruitment estimates, seedlings were classified as either an incoming seedling or an old seedling. Old seedlings are those older than one year and easily recognizable because they have (or there is evidence that they had produced), more than two leaves and their leaflet coloration is darker than those of the incoming seedlings $(<1 \mathrm{yr}$ old $)$. These phenotypic differences make it easy to detect when seed establishment occurred. For saplings, we measured height, and both diameters at the base (DB) and breast height (DBH) were measured. Damage on saplings due to falling branches from the forest canopy, as indicated by scars, was also measured.

Hypothesis 1: "Seed distribution hypothesis," if dispersal at random then the per sub-plot variance to mean ratio of the distribution of seeds is not statistically different from a Poisson process. Hypothesis 2: "Seedling recruitment hypothesis," the observed fraction of sub-plots receiving seedling recruitment is less than the one expected under the assumption of random establishment. In order to address hypothesis 1 and 2, the variance to mean ratio was computed as a measure of the spatial distribution of seeds, seedlings and saplings. The arithmetic mean $=\mathrm{N} / \mathrm{J}$, which corresponds to the total 
number of individuals per sub-plot divided by the total number of sub-plots. The variance

$$
\frac{\sum_{i=1}^{J} i(m-n)^{2}}{J-1}
$$

where: $i=$ number of sub-plots, $n=$ number of individuals per sub-plot, $m=$ arithmetic mean and $J=$ total number of sub-plots. Observed values were compared with expected values from a Poisson distribution (Zar 1999, Vandermeer and Goldberg 2003). The Wilcoxon test was used to test for differences between observed numbers of individuals (seeds, seedlings or saplings) per unit of area against the theoretical Poisson distribution expectation of individuals/stage per sub-plot. A non-parametric test was used because of the scale dependency of variance to the mean ratio estimates. In order to determine the relationship between seedling establishment distribution with respect to the nearest conspecific adult tree, we used a point pattern analysis approach, in specific the bivariate Ripley's K function. The bivariate Ripley's K function represents the average distance relationships, because all the pairwise point distances between the two size-stages (established seedlings and D. oleifera trees) are included in its calculation. The observed bivariate Ripley's K function was plotted against 9 999 Monte Carlo replications (Baddeley 2006). Because seeds censuses were completed only after several field trips (about 3 to 4 fields trips during seed production season), the bivariate Ripley's K function underestimates the dynamic seed dispersal process. Consequently, we do not report these results here, however from our field observations we understand that bat seed dispersal congregated seeds below bat roosting sites away the nearest conspecific adult (Ruiz and Boucher submitted).

During the testing process of hypotheses 1 and 2, in addition to the seed and seedling distributions, we also computed the basic seed and seedlings recruitment limitation estimates following standard methodology (Nathan and Muller-Landau 2000, Muller-Landau et al. 2002). In order to assess fundamental seed limitation, we observed the seed rain at each $10 \times 10 \mathrm{~m}$ sub-plot within the 6.37 ha plot for 2003-2004, 1.27 ha in 2005 and 3.38 ha in 2006. Fundamental seed limitation was computed as the fraction of sites not reached by seeds within the study area. The optimal establishment scenario would be that an adult tree establishes at every site receiving one or more seeds. Therefore, fundamental seedling limitation was calculated as the fraction of sites without seedlings. The establishment niche is defined as the fraction of sites where seedlings survive one or more years (Muller-Landau et al. 2002). Seedling establishment occurs when a seedling stays in the forest floor for more than a year (Dalling and Hubbell 2002, Dalling et al. 2002).

For saplings we did not compare the observed distribution with the theoretical Poisson distribution or the bivariate Ripley's $\mathrm{K}$ function because saplings were generally singleton individuals per sub-plot. From March 2002 to April 2002 we counted how many times saplings presented broken stems and compared this kind of sapling damage with sapling relative growth rate from 2002-2003 using a linear regression model.

Hypothesis 3: If seedling insect herbivory damage decreases with the distance to the nearest conspecific adult tree of $D$. oleifera, then seedling survival will be high away from it. In order to determine the effect of insect herbivory on seedling recruitment dynamics a digital photograph of the leaves of each seedling was taken from above the seedling canopy. Leaf area damaged by insect herbivory was evaluated from digital photographs taken in early January of 2005 and 2006. Leaflets of D. oleifera are remarkably horizontal which allowed us to visually count the percentage of herbivory per leaflet. Leaf area damage per leaflet was summed up and divided by the total number of leaflets in order to assess the averaged percentage of herbivory 
per seedling. To determine the accuracy of the visual estimation, leaf damage was also measured using a grid on 100 seedlings. There was no significant statistical difference between the methods, allowing us to use the fastest method of visual estimation. We use regression models, only the models with the highest R-square value were used in order to determine whether insect herbivory damage depends on the distance from the nearest conspecific adult tree.

Hypothesis 4: If seedling relative growth rate decreases as a function of the distance to the nearest conspecific adult tree, then there is evidence suggesting a positive correlation between lower insect herbivory away the adult $D$. oleifera and faster seedling growth rate. In order to test this hypothesis, we computed relative growth rate (RGR), this is measured as the proportion of the change in height. This is the basic RGR calculated by the formula $R G R=\ln (X(t+1))-\ln (X(t))$, where $\ln (X(t))$ is the natural logarithm of the height at time $t$ and $\ln (X(t+1))$ is the natural logarithm of the height at time $t+1$. RGR represents the velocity at which height is growing or degrowing. Linear models were fitted in order to determine whether seedling relative growth rate correlates with the distance from the nearest conspecific adult tree.

Hypothesis 5: If seedling mortality is negatively correlated with the number of conspecific saplings, then insect herbivore might be using sapling as a way to cue in on seedlings. Seedling survival per measurement period was evaluated using linear models. A first model studied seedling survival $\left(Y_{t}\right)$ a function of seedling density per sub-plot in the previous year $\left(S_{t-1}\right)$ and sapling number in the previous years $\left(P_{t-1}\right)$ :

$$
Y_{t}=\mu+\alpha S_{t-1}+\beta P_{t-1}+\varepsilon \text { (Formula 1). }
$$

where $\mu$ is the intercept or the average survival of seedlings per sub-plot, $\alpha$ is a parameter relating seedling survival for period $(t, t+1)$ with the density of seedlings in the previous year $(t), \beta$ accounts for the additional change in seedling survival due to the presence of saplings in each year. The model number 4 in Table 4 was analyzed using an ANCOVA to test for the significance of each predictor.

\section{RESULTS}

Hypothesis 1: "Seed distribution hypothesis," if dispersal is at random then the per sub-plot variance to mean ratio of the distribution of seeds is not statistically different from a Poisson process. Early during the seed production, seed distributions were clumped and, statistically different form a Poisson process. Seed aggregation is higher near than away the nearest conspecific adult trees. Seed dispersal is high with seeds reaching about $40 \%$ of the sub-plots during the year with the lowest seed dispersal and, about $60 \%$ during the year with the highest seed dispersal (Table 1).

Hypothesis 2: "Seedling recruitment hypothesis," the observed fraction of subplots receiving seedling recruitment is less than the one expected under the assumption of random establishment. Results of the yearly variance to mean ratio for seedlings from 2002 to 2006 show that seedling recruitment and seeding establishment are clumped (Table 1). Seedling mortality is highly clumped near to a conspecific tree (Figure 1,2), and seedling recruitment is clumped between about 40-80 $\mathrm{m}$ from the nearest conspecific adult tree during the periods 2003-2004, 2004-2005 and 2005-2006. On the contrary, results for period 2002-2003 were no different from a random distribution (Figure 3).

Results on seedlings establishment show that seedling survival is high away the nearest conspecific adult tree. This finding is supported by the seedling survival analysis, which showed that survival increased as a statistically significant dependent function of the distance to the nearest conspecific adult trees for all periods: 2002-2003, 2003-2004, 2004-2005 and, 20052006 (Logistic regressions $\mathrm{R}^{2}=0.1360, \mathrm{n}=$ 261 seedlings, $\mathrm{P}=0.000 ; \mathrm{R}^{2}=0.7630, \mathrm{n}=1906$ 
TABLE 1

Variance to mean ratio for spatial distribution of seeds, seedlings and sapling of D. oleifera from 2002 to 2006. Observed seedling distributions were tested against a Poisson distribution using a probability $<0.05$. Sample size " $n$ " is number of individuals at the beginning of the research period. Totals of surviving and dead individuals do not add up to " $n$ " because transitions from/or to upper stages had occurred

\begin{tabular}{|c|c|c|c|c|}
\hline Category & Ratio & $\mathrm{N}$ & $\mathrm{P}=$ & Distribution \\
\hline Seeds 2003 & 864 & 1195 & 0 & Clumped \\
\hline Seeds 2004 & 76.91 & 783 & 0 & Clumped \\
\hline Seeds 2005 & 1280 & 593 & 0 & Clumped \\
\hline Seeds 2006 & 1649 & 2303 & 0 & Clumped \\
\hline Seedlings 2002 & 7.82 & 299 & 0.028 & Clumped \\
\hline Seedlings 2003 & 26.09 & 1545 & 0.002 & Clumped \\
\hline Seedlings 2004 & 1.73 & 1496 & 0 & Clumped \\
\hline Seedlings 2005 & 19.37 & 2297 & 0.001 & Clumped \\
\hline Seedlings 2006 & 57.71 & 2496 & 0.001 & Clumped \\
\hline Seedling establishment 2002-2003 & 12.06 & 194 & 0.028 & Clumped \\
\hline Seedling establishment 2003-2004 & 3.81 & 724 & 0.028 & Clumped \\
\hline Seedling establishment 2004-2005 & 23.38 & 825 & 0.002 & Clumped \\
\hline Seedlings establishment 2005-2006 & 23.91 & 1441 & 0.005 & Clumped \\
\hline Seedling mortality $2002-2003$ & 5.96 & 103 & 0.028 & Clumped \\
\hline Seedling mortality $2003-2004$ & 14.66 & 815 & 0 & Clumped \\
\hline Seedling mortality $2004-2005$ & 10.23 & 648 & 0.005 & Clumped \\
\hline Seedling mortality $2005-2006$ & 28.88 & 968 & 0.001 & Clumped \\
\hline Saplings 2002 & 1.191 & 105 & & Slightly clumped \\
\hline Saplings 2003 & 0.991 & 68 & & Slightly even \\
\hline Saplings 2004 & 0.910 & 74 & & Slightly even \\
\hline Saplings 2005 & 0.938 & 66 & & Slightly even \\
\hline Saplings 2006 & 0.041 & 74 & & Slightly even \\
\hline Saplings establishment 2002-2003 & 1.120 & 55 & & Slightly clumped \\
\hline Sapling establishment 2003-2004 & 1.656 & 56 & & Slightly clumped \\
\hline Sapling establishment 2004-2005 & 0.833 & 57 & & Slightly even \\
\hline Sapling establishment 2005-2006 & 0.911 & 60 & & Slightly even \\
\hline Sapling mortality $2002-2003$ & 0.963 & 44 & & Slightly even \\
\hline Sapling mortality $2003-2004$ & 1.645 & 6 & & Slightly clumped \\
\hline Sapling mortality 2004-2005 & 1.042 & 5 & & Slightly clumped \\
\hline Sapling mortality 2005-2006 & 1.000 & 3 & & Random \\
\hline
\end{tabular}



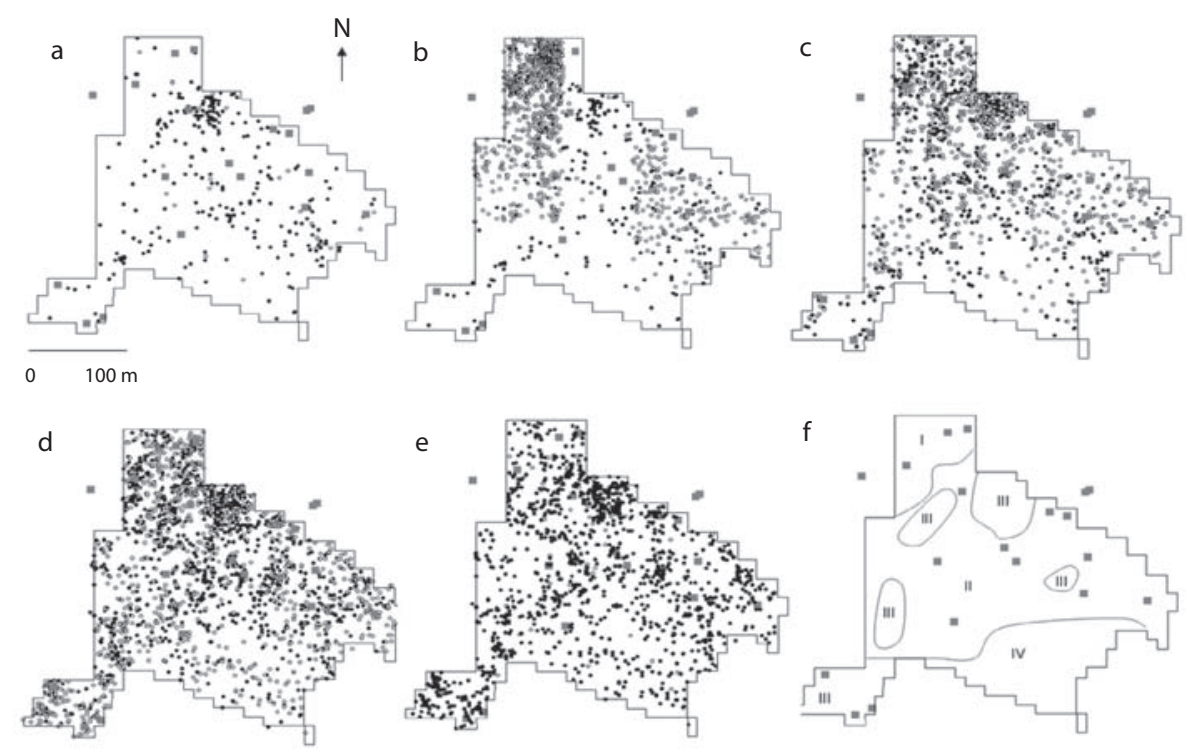

Fig. 1. Observed distribution of seedlings and adult trees within a 6.37 ha research plot in Southeast Nicaragua from 2002 to 2006. Gray squares represent adult tree individuals ( () ; black solid circles represent seedlings older than one year $(\bullet)$ and open circles are incoming seedlings (O). Low caption letters represent consecutive years since the beginning of the research in 2002. I) clumps with high number of seedlings nearby adult trees; II) clumps with low number of seedlings further from large adult trees (northern area); III) Clump with high number of seedlings and IV) with low number of seedlings.

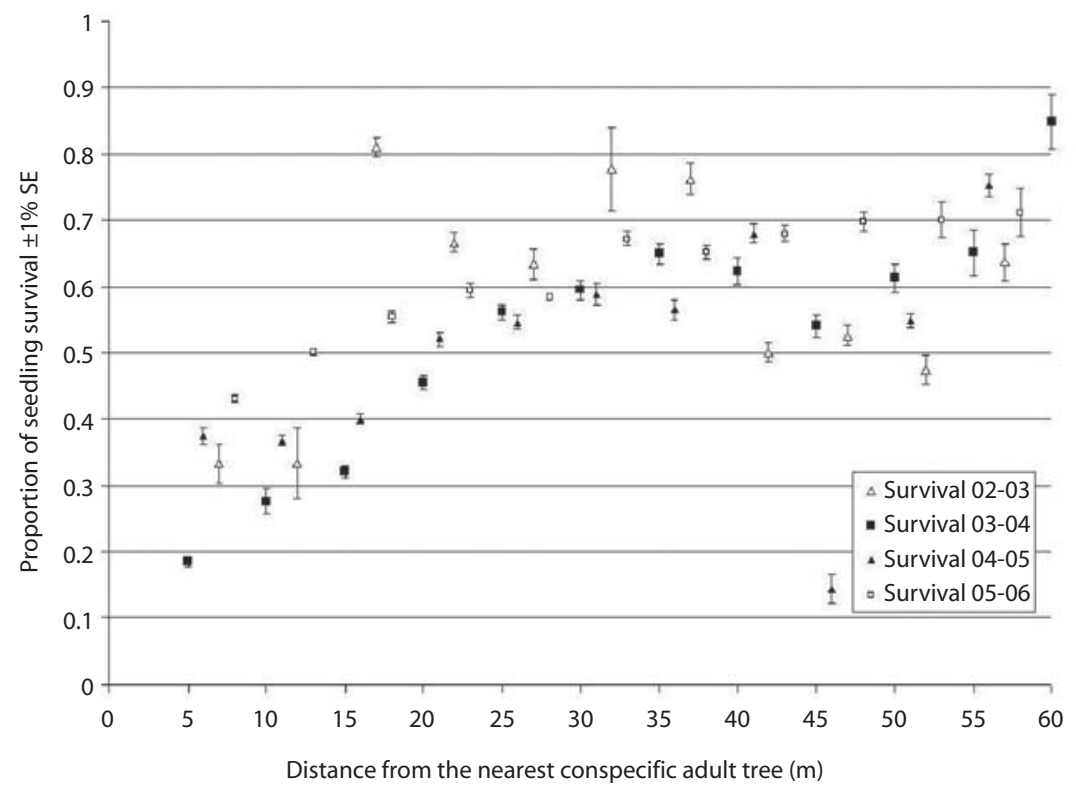

Fig. 2. Weighted mean of seedling survivorship probability of $D$. oleifera versus distance to nearest conspecific adult tree for periods 2002 to 2006. Seedling survival was calculated from 0 to $60 \mathrm{~m}$ per each $5 \mathrm{~m}$ distance interval with respect to 14 reproductive individuals within a 6.37 ha research plot. Error bars are the standard errors of weighted mean of seedling survival per distance interval between adult individuals located within the research plot. 

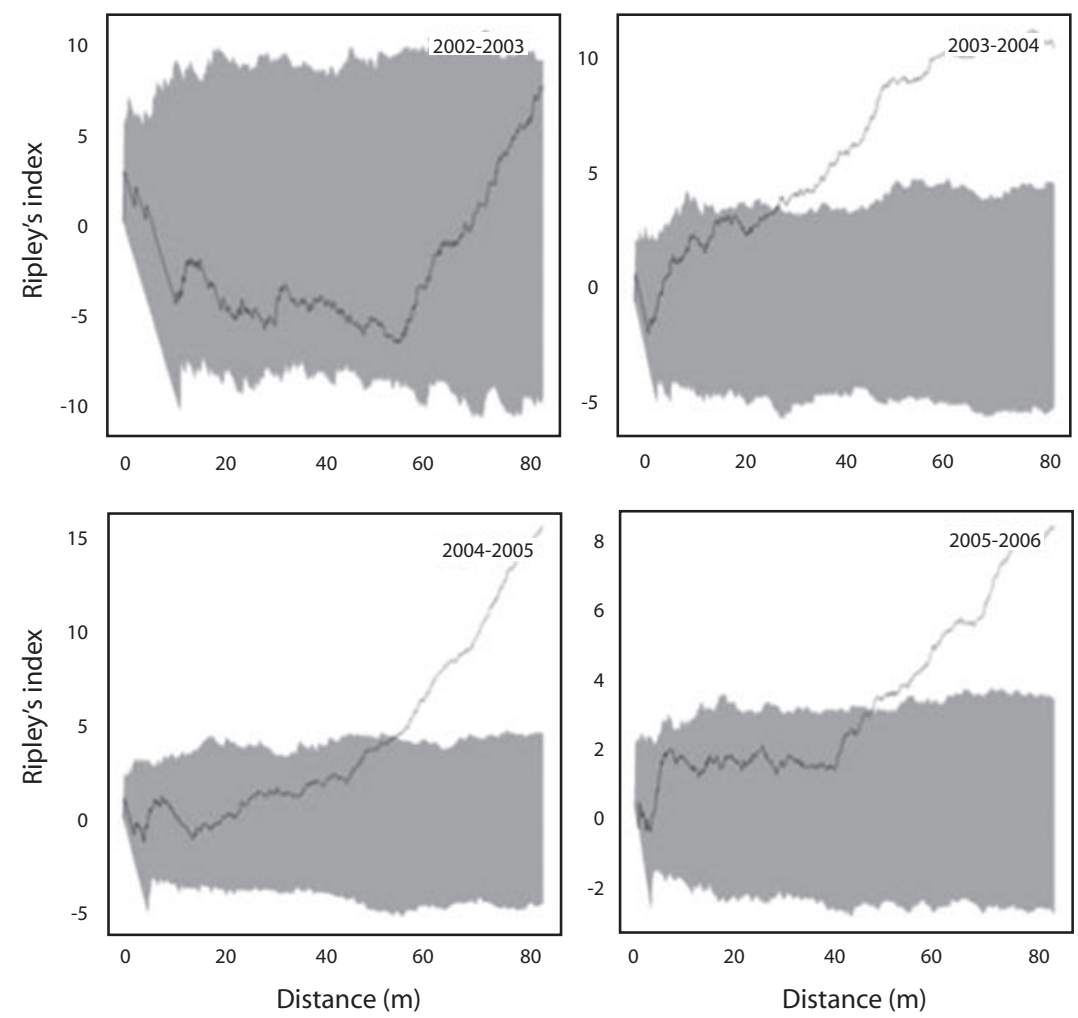

Fig. 3. Linearized Ripely's K test. Line is the computed function form observations. Shaded area are 9999 Monte Carlo replications. Seedling establishment distribution did not differs form a random spatial distribution in 2002 to 2003 , because seedling were rare.

seedlings, $\mathrm{P}=0.000 ; \mathrm{R}^{2}=0.858, \mathrm{n}=1373$ seedlings, $\mathrm{P}=0.000$ and $\mathrm{R}^{2}=0.7270, \mathrm{n}=2$ 141 seedlings, $\mathrm{P}=0.000$, respectively) (Figure 2, see Figure 3).

Hypothesis 3: If seedling insect herbivory damage decreases with the distance to the nearest conspecific adult tree of $D$. oleifera, then seedling survival will be high away from it. The results showed that seedling herbivory decreased linearly with the distance to the nearest adult $D$. oleifera in period 2004$2005\left(\mathrm{R}^{2}=0.3308, \mathrm{P}=0.0314, \mathrm{n}=1226\right)$. The distribution of insect herbivory fitted a quadratic function with respect to the adult tree in the period 2005-2006 $\left(\mathrm{R}^{2}=0.7379, \mathrm{P}=0.0001\right.$, $\mathrm{n}=884$ ) (Figure 4).
Hypothesis 4: If seedling relative growth rate decreases as a function of the distance to the nearest conspecific adult tree, then there is evidence suggesting a positive correlation between lower insect herbivory away the adult $D$. oleifera and faster seedling growth rate. Seedling relative growth rates with respect to the distance to the nearest adult D. oleifera tree were fitted to a linear function (Figure 5a,b). The slopes of the linear functions were very close to zero $(p<0.01)$, for each measurement period.

Hypothesis 5: If seedling mortality is negatively correlated with the number of conspecific saplings, then insect herbivore might be using sapling as a way to cue in on 


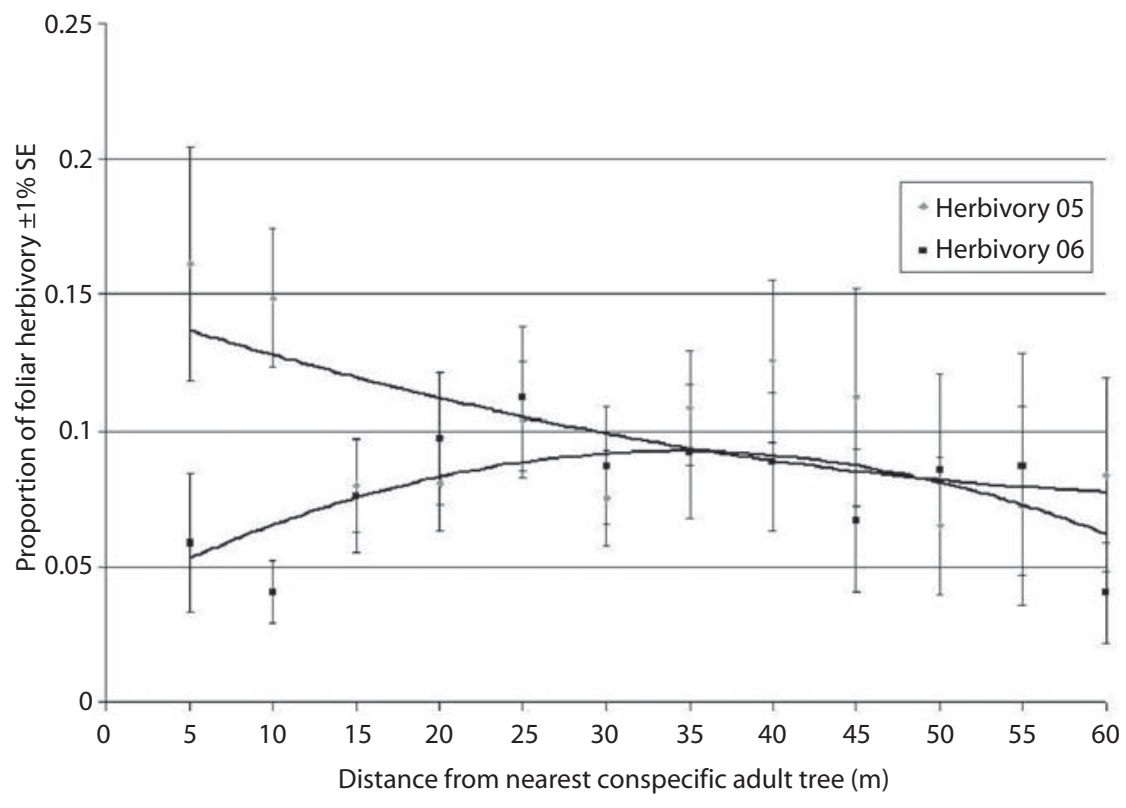

Fig. 4. Proportion of insect herbivory as a function of the distance to the nearest conspecific D. oleifera adult tree (m). Curves represent a statistically significant logistic fit for insect herbivory in year 2005 and a statistically significant quadratic fit for insect herbivory in year 2006. Error bars are the standard errors in seedlings insect herbivory between adult individual per distance interval $(5 \mathrm{~m})$.

TABLE 2

The results of the fundamental seed and seedling limitation and seedling establishment limitation for the years 2003 to 2006. Calculations were conducted within a sub-plot of 6.37 divided in sub-plots of $10 \times 10 \mathrm{~m}$

$\begin{array}{llcccc}\text { Year } & \text { Analysis } & \begin{array}{c}\text { Sub-plots } \\ \text { with seeds }\end{array} & \begin{array}{c}\text { Total } \\ \text { sub-plots }\end{array} & \text { Formulation } & \text { Result } \\ 2003 & \text { Seed limitation } & 52 & 127 & 1-(52 / 127) & 0.4094 \\ 2004 & \text { Seed limitation } & 87 & 127 & 1-(87 / 127) & 0.6850 \\ 2005 & \text { Seed limitation } & 59 & 175 & 1-(59 / 175) & 0.6628 \\ 2006 & \text { Seed limitation } & 172 & 338 & 1-(172 / 338) & 0.4911 \\ 2002 & \text { Seedling limitation } & 117 & 637 & 1-(117 / 637) & 0.8163 \\ 2003 & \text { Seedling limitation } & 286 & 637 & 1-(286 / 637) & 0.5510 \\ 2004 & \text { Seedling limitation } & 447 & 637 & 1-(447 / 637) & 0.4553 \\ 2005 & \text { Seedling limitation } & 436 & 635 & 1-(436 / 635) & 0.3155 \\ 2006 & \text { Seedling limitation } & 436 & 635 & 1-(462 / 635) & 0.2747 \\ 2002-2003 & \text { Seedling establishment limitation } & 155 & 338 & 1-(155 / 338) & 0.5414 \\ 2003-2004 & \text { Seedling establishment limitation } & 154 & 637 & 1-(154 / 637) & 0.7582 \\ 2004-2005 & \text { Seedling establishment limitation } & 331 & 635 & 1-(331 / 635) & 0.4804 \\ 2005-2006 & \text { Seedling establishment limitation } & 179 & 637 & 1-(179 / 637) & 0.7190 \\ 2002-2006 & \text { Seedling establishment limitation } & 381 & 637 & 1-(381 / 637) & 0.4019\end{array}$




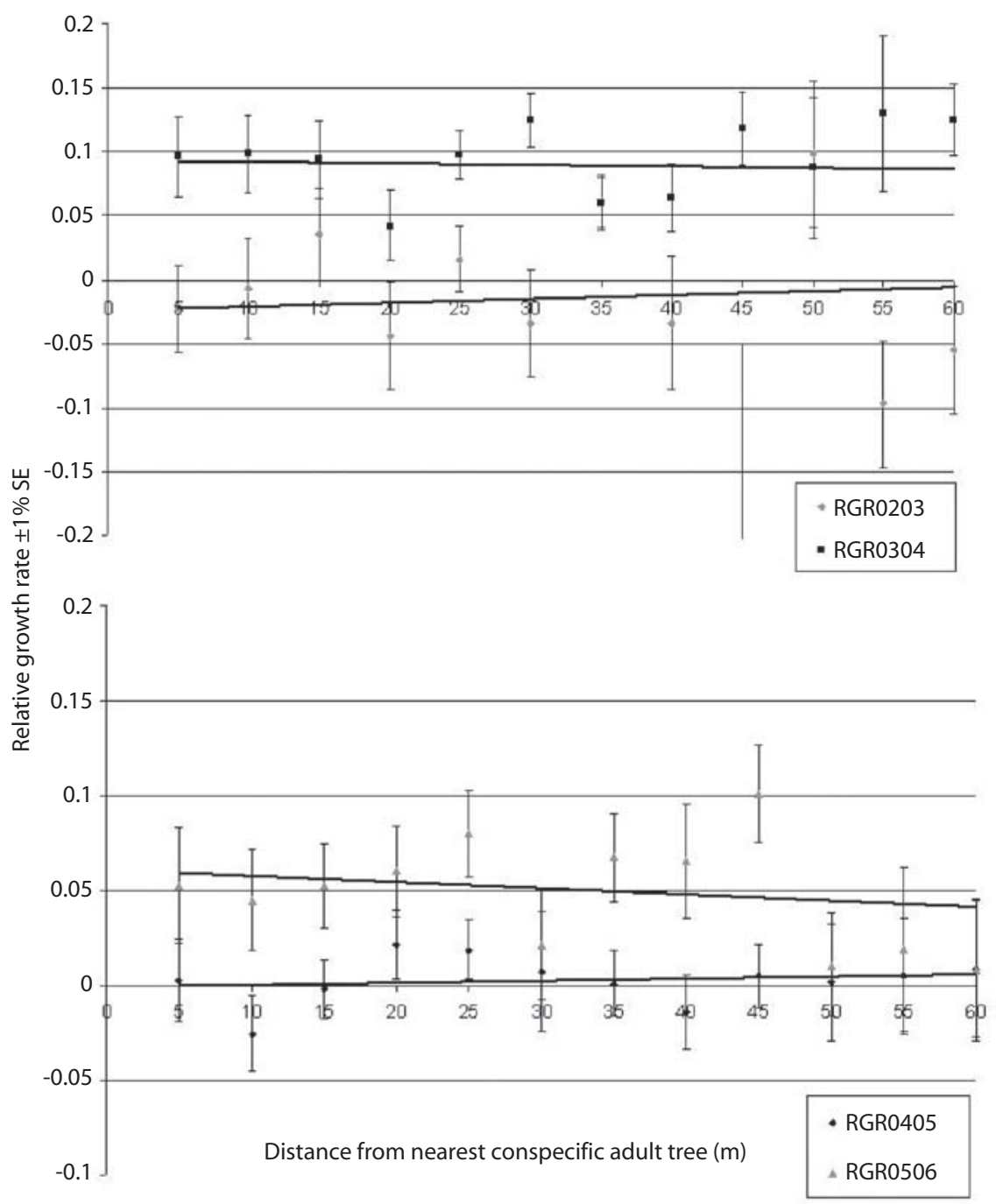

Fig. 5. Seedling relative growth rates as a function of the distance to the nearest conspecific D. oleifera adult tree (m). Lines represent a linear fit and error bars is the $1 \%$ standard errors in seedling growth rates between adult tree per distance interval (5 m).

seedlings. An ANCOVA model showed that seedling survival 2005-2006 was negatively correlated with the density of saplings per sub-plot in 2005 (Table 4). Sapling growth is not related to the distance with respect to the nearest conspecific adult tree for each period from 2002 to 2006 ( $\mathrm{F}=0.707$, df $=12, \mathrm{P}=$ $0.728 ; \mathrm{F}=0.495, \mathrm{df}=12, \mathrm{P}=0.896 ; \mathrm{F}=1.128$, $\mathrm{df}=12, \mathrm{P}=0.379 ; \mathrm{F}=0.923, \mathrm{df}=12, \mathrm{P}=$ 0.536 , respectively). Results of the mean to variance ratio for the sapling stage from 2002 to 2006 suggest that the sapling distribution is at random (Table 1). The weighted mean of the percentage of seedling making the transitions to sapling is $0.77 \%$ from $2002-2006$ (Table 3). Furthermore, there is a negative trend between sapling growth and the number of stems damaged by litter and twigs falling form the canopy in the period 2002-2003 $\left(\mathrm{R}^{2}=-0.1058, \mathrm{df}=22\right.$, $\mathrm{P}=0.1210)$. 
TABLE 3

Seedling fate, seedling transition to sapling and sapling fate for the period 2002-2006. The overall weighted transition from the seedling to sapling stage is $0.77 \%$. A number of individuals made the transition from the upper stage to saplings ("de-growth"); since these represent a minimal number of individuals these figures are not presented here

$\begin{array}{lcccccc}\text { Stage } & \text { Period } & \text { Survival } & \text { Mortality } & \text { Transition } & \text { Sample } & \text { Total } \\ \text { Seedling } & & \% & \% & \% & \mathrm{n} & \mathrm{N} \\ \text { Seedling } & 2002-2003 & 62.96 & 37.04 & & & \\ \text { Seedling } & 2003-2004 & 55.81 & 44.20 & & \\ \text { Seedling } & 2004-2005 & 51.23 & 48.80 & & \\ \text { Sapling } & 2005-2006 & 56.18 & 43.82 & & \\ \text { Sapling } & 2002-2003 & 52.38 & 47.62 & & \\ \text { Sapling } & 2003-2004 & 82.35 & 17.65 & & & \\ \text { Sapling } & 2004-2005 & 77.03 & 22.97 & & & \\ \text { Seedling to sapling } & 2005-2006 & 90.91 & 9.091 & & 2 & 299 \\ \text { Seedling to sapling } & 2002-2003 & & & 0.67 & 1 & \\ \text { Seedling to sapling } & 2003-2004 & & & 3.11 & & \\ \text { Seedling to sapling } & 2004-2005 & & & 0.16 & 13\end{array}$

\section{DISCUSSION}

Hypothesis 1: "Seed distribution hypothesis," if dispersal is at random then the per sub-plot variance to mean ratio of the distribution of seeds is not statistically different from a Poisson process. Our analyses showed that seed distribution is highly clumped and strongly different from the theoretical Poisson random distribution. This clumped distribution is due, to some extent, to the overwhelming seed movement by gravity from the crown of the adult tree. This result is consistent with the field observations carried out by Clark and Clark (1984) in Costa Rica, where about $80 \%$ of seed production was close $(<9 \mathrm{~m})$, to the nearest adult tree - crown radii for six adults within the plot ranged from 7.7 - to $21.3 \mathrm{~m}$; the mean crown radii of an adult $D$. oleifera in the Nicaraguan population is approximately $13 \mathrm{~m}$, which is within this crown radii range.

Field observations lead us to believe that the biological agent controlling seed mortality below the adult $D$. oleifera trees is the larval stage of a fly of the genus Taeniaptera, under taxonomical study by Jean-Michel Maes
(Museo Entomológico de Nicaragua) and Steve Marshall (University of Guelph). Seed predation occurs when seeds are germinating and larvae reach the seeds through the small opening ( $\sim 1 \mathrm{~mm}$ ) between valves. The observed number of larvae varied from few to hundreds per seed. During 2006 we observed that this type of seed damage seemed to be positive densitydependent, as high larval seed consumption corresponded with the peak of seed production (around June) below the reproductive adult trees (unpublished data). This is the first study reporting larval seed predation on seeds of $D$. oleifera in the literature. Despite the fact that, field studies reporting insect seed predation in tropical rainforest studies are frequent (Wilson and Janzen 1972, Bradford and Smith 1977, Wright 1983). Since terrestrial mammal seed predation could be important we observed whether mammal seed predation was frequent, but there was no seed dispersal by terrestrial mammals from below the adult trees in 2006 (Ruiz et al. in preparation), suggesting that below adult trees terrestrial mammals are not the major force driving seed mortality but the seed predator insect. 
TABLE 4

a) Analysis of Covariance (ANCOVA) for the model presented in formula 1

\begin{tabular}{|c|c|c|c|c|c|}
\hline Model & Independent variable & D.F. & Sum Sq & $F$ value & $P$ \\
\hline \multirow[t]{3}{*}{1} & Seedling density $\left(Y_{2002}\right)$ & 1 & 0.0557 & 0.33520 & 0.5649 \\
\hline & Sapling density $\left(S_{2002}\right)$ & 2 & 0.01126 & 0.33888 & 0.7141 \\
\hline & Error $(\varepsilon)$ & 56 & 9.3038 & & \\
\hline \multirow[t]{3}{*}{2} & Seedling density $\left(Y_{2003}\right)$ & 1 & 0.042 & 0.2947 & 0.5876 \\
\hline & Sapling density $\left(S_{2003}\right)$ & 2 & 0.250 & 0.8731 & 0.4187 \\
\hline & Error $(\varepsilon)$ & 305 & 43.709 & & \\
\hline \multirow[t]{3}{*}{3} & Density seedlings $\left(Y_{2004}\right)$ & 1 & 0.132 & 0.9224 & 0.3374 \\
\hline & Sapling density $\left(S_{2004}\right)$ & 2 & 0.269 & 0.9418 & 0.3908 \\
\hline & Error $(\varepsilon)$ & 402 & 57.415 & & \\
\hline \multirow[t]{3}{*}{4} & Seedling density $\left(Y_{2005}\right)$ & 1 & 0.069 & 0.5958 & 0.4405 \\
\hline & Sapling density $\left(S_{2005}\right)$ & 1 & 0.554 & 4.8146 & $0.0287 *$ \\
\hline & Error $(\varepsilon)$ & 533 & 61.368 & & \\
\hline
\end{tabular}

* Statistically signif. $(\mathrm{P}<0.05)$.

b) Coefficients for the ANCOVA model see text for details

$\begin{array}{lcccc}\text { Parameter } & \text { Estimate } & \text { S.E. } & t \text { value } & \text { P } \\ \text { Intercept }(\mu) & 0.37269 & 0.02638 & 14.130 & <2 \mathrm{e}-16^{*} \\ \text { Seedling density } 05(\alpha) & 0.05832 & 0.06683 & 0.873 & 0.3832 \\ \text { Saplings }(1) 05\left(\beta_{1}\right) & -0.14621 & 0.04851 & -3.014 & 0.0027 * * \\ \text { Saplings }(2) 05\left(\beta_{1}\right) & -0.39602 & 0.33829 & -1.171 & 0.2423\end{array}$

* Statistically signif. $(\mathrm{P}<0.05), * *$ Statistically signif. $(\mathrm{P}<0.01)$.

Seed dispersal away from the adult tree leaded to $68 \%$ of the research area receiving seeds during a highly productive year, which is very high considering that $D$. oleifera has large seeds. Because seed censuses were carried out early during the fruiting seasons, our estimations of the clumped distribution of seeds are mainly due to seed aggregations nearby and, to some extend, away the conspecific tree. In a field experiment conduced in 2006 we evaluated the seed dispersal dynamics of $D$. oleifera by attaching a nylon string to all seedling in 3.2 ha sub-plot within the study plot $(\mathrm{N}=3555)$. The results from these assessment showed that bats congregated seeds away the adult tree (primary dispersal). Rodents, on the other hand, were able to find seed piled by bats in the forest understory. During this process rodents consumed some seeds and moved other seeds throughout the forest floor (secondary seed dispersal). As a consequence, a clumped distribution of seeds away the adult tree was not observed toward the end of the seed production period (Ruiz et al. submitted).

Hypothesis 2: "Seedling recruitment hypothesis," the observed fraction of subplots receiving seedling recruitment is less 


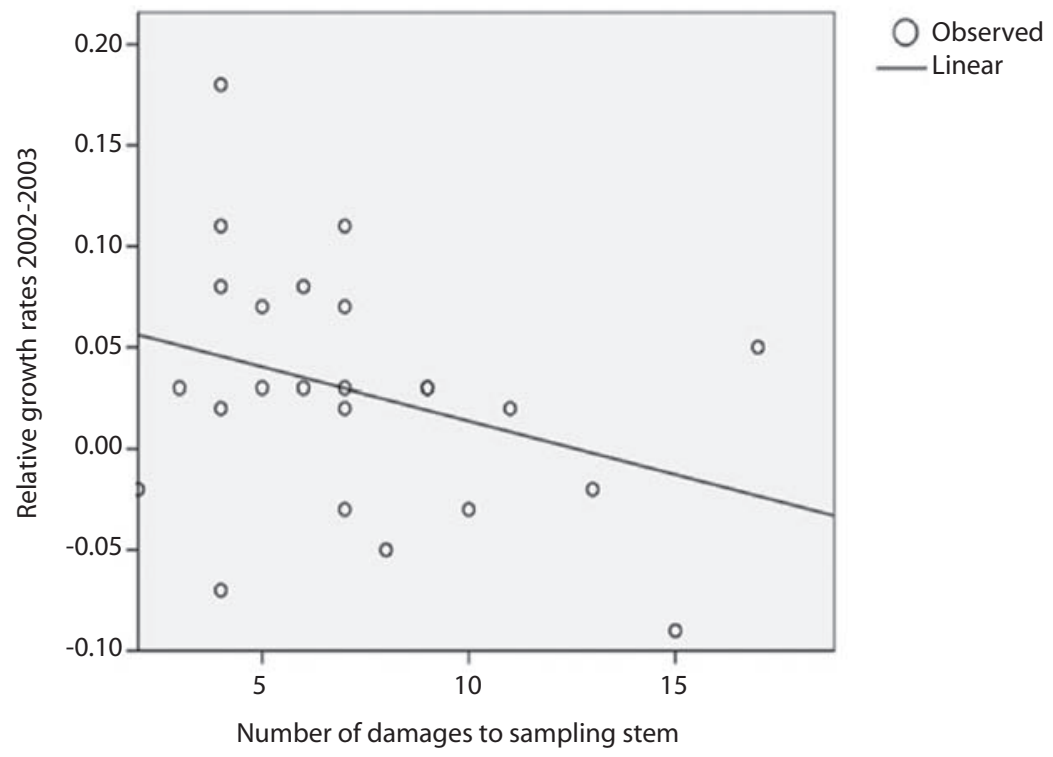

Fig. 6. Sapling growth rate (2002-2003) as a function of the number of stem damage due to falling branches from the forest canopy.

than the one expected under the assumption of random establishment. The results support the hypothesis that seedling distribution is clumped throughout the research period and strongly different from a theoretical Poisson distribution (Table 1). Figure 2 shows that seedling establishment occurred away from adult trees, as expected by the natural enemies control hypothesis (Janzen 1970, Connell 1971, Howe and Smallwood 1982). Because, seedling survival is high away form conspecific adult trees, these seedling clumps were located away form the adult $D$. oleifera tree (Figure $1,3)$. Our estimation of this seedling survival patterns is also consistent with the observations made by the Clark and Clark (1984). In their study of the cohort 1980 , only $33 \%$ of the seedlings survived toward the end of 1980 and, $37 \%$ seedling survival close $(<13 \mathrm{~m})$ from the nearest adult tree. No seedling within $8 \mathrm{~m}$ from the nearest adult tree survived to the age of 21 months. For seedlings, at least 19\% survived beyond $22 \mathrm{~m}$ from the nearest adult tree to the age of 2 yr. They also found that seedling survival was negatively correlated with seedling density $(\mathrm{P}<0.005)$. Seven months after germination, the seedling number was higher closer to the nearest conspecific adult tree. Both interseedling competition and, adult interference were rule out as factor determining seedling survival patterns (Clark and Clark 1985).

In addition we found evidence showing that seedling limitation was higher toward the beginning of the study and less pronounced after two highly productive years (2005 and 2006). Only $12 \%$ of the area did not receive seedlings at any given period in time. However, seedling establishment ( $\geq 1 \mathrm{yr}$ after germination) only occurred in $\sim 40 \%$ of the study area during the whole research period (black circles in Figure 1). These results showed that the population of D. oleifera in eastern Nicaragua is not recruitment limited at the seedling stage.

Hypothesis 3: If seedling insect herbivory damage decreases with the distance to the nearest conspecific adult tree of $D$. oleifera, then seedling survival will be high away from it. Our results suggest that seedling mortality could be due to insect herbivory 
nearby adult $D$. oleifera trees. The overall seedling mortality was two-fold higher when foliar herbivory damage was about $20 \%$ during the previous measurement period (Ruiz et al. submitted). Seedling distributions in Figure 1 suggest that the areas with higher number of seedlings are more ephemeral than those with fewer seedlings, which appeared to be more permanent during the research period. These observations also lead us to think that there is positive density-dependent effect of insect herbivores within the research plot but this effect is stronger nearby the adult tree (Figure 4).

Our results are also complementary to findings reported earlier where seedling herbivory accumulated over time and, it was positively correlated with seedling density and, decreased with respect to the distance to the nearest cospecific adult tree (Clark and Clark 1985). In the Costarican population studied by Clark and Clark (1985), seedling longevity correlated with leave area at 1 mo and 7 mo of age. They found that in the dense population, seedling longevity, at least 1 mo after germination, was negatively correlated with the leave area lost due to herbivory ( 16 censuses, 1.3 yrs, $\mathrm{R}^{2}=$ $-0.26, \mathrm{P}<0.002, \mathrm{~N}=42$ ). For experimentally isolate seedlings, survival was positively correlated with the leave area remaining 1 mo after transplanting (11 censuses over $1.3 \mathrm{yr}, \mathrm{R}^{2}=$ $0.59, \mathrm{P}<0.002, \mathrm{~N}=18$ ). Of the 13 isolated with $\geq 99 \%$ leave area present at 1 mo after planting (2mo post-germination), $85 \%$ survived after 1 yr. All isolated seedlings with $\leq 99 \%$ of leave area experienced mortality $(\mathrm{N}=5)$, this is striking considering the small insect herbivory levels $(\leq 8 \%)$ during the first two months after germination generally resulted in mortality. Similarly, small levels of insect herbivory $(\sim 25 \%)$ correlated positively with seedling mortality in the Nicaraguan population (Ruiz et al. submitted). Because isolated seedling experienced lower herbivory and higher survival in the fieldwork conducted by Clark and Clark (1985), we think that our results of the bivariate Ripley's K function strongly suggest that seedling survival in $D$. oleifera occurs in small natural isolated clumps away the conspecific tree (Figure 1,3).
Hypothesis 4: If seedling relative growth rate decreases as a function of the distance to the nearest conspecific adult tree, then there is evidence suggesting a positive correlation between lower insect herbivory away the adult $D$. oleifera and faster seedling growth rate. Our result showed that RGR is not correlated with the distance to the nearest conspecific adult tree. Therefore, we did not find evidence suggesting that lower seedling insect herbivory damage and seedling survival positively correlated with higher seedling growth rate. However, we found evidence that sapling growth rate is negatively related to apical meristem damage, notice that multiple agents could be responsible for this kind of damage. The apparently broken meristems could have been, bitten by an insect herbivore, broken by fallen litter, or damaged by localized fungal attack. Appical meristem damage seems to be more severe closer to than away from the nearest D. oleifera adult in the Costarican population (Clark and Clark 1985), but this is not the case in the site in Nicaragua, because this damage seems to be randomly distributed.

Hypothesis 5: If seedling mortality is negatively correlated with the number of conspecific saplings, then insect herbivore might be using sapling as a way to cue in on seedlings. Since our results showed that seedling survival 2005-2006 was negatively correlated with the number of saplings in 2005. We think that this evidence is in favor of the idea that insect herbivores could be responding positively to the presence of larger stages $-i$. $e$. density responsive natural enemies (Janzen 1970).

The evaluation of the sapling recruitment dynamics showed that sapling recruitment appears to be at random. This is related to the fact that according to our censuses of the demography of $D$. oleifera, the transition from seedling to sapling stage is a rare event. Specifically, the cumulative percentage of seedling transitions to sapling stage was only $0.77 \%$. Sapling survival was very high $(>77 \%)$ over the research period, similar to the annual 
survival rate of 1-2 cm DBH saplings, 98.0 $\%$ for Trichilia tuberculata, and $84.4 \%$ for Miconia argentea in a field study conducted at BCI (Muller-Landau et al. 2004). Much of the observed sapling mortality may be due to branches falling from the upper stories as observed earlier (Clark and Clark 1987), and as also noticed in our observational study.

Sapling relative growth rate was independent with respect to the distance to the nearest conspecific adult tree (Clark and Clark 1987). In another field study conducted in a tropical rainforest in Costa Rica, maximum height of seedlings of $D$. oleifera was positively related with light intensity reaching the forest floor. Light intensity, a measure of canopy openness, was not correlated with the maximum height and the position of juveniles in the canopy (Clark and Clark 1987). We hope to test whether the transition from seedling to sapling stage depends on microsite conditions, in specific: "mini light-gap formations". Mini light-gaps are small apertures in a closed forest canopy by which light attenuates through lower forest stories. We also hope to fit statistical functions relating the effect of light intensity on the transition from seedling to sapling, relative growth rate in diameter and maximum height in a future communication.

Life history and seedling recruitment dynamics: The recruitment dynamics in $D$. oleifera is strongly determined by dispersal away form the adult tree, which is related with lower levels of insect herbivory and higher survival rate. Herbivory and other factors resulted in mortality of $60 \%$ of the seedlings and the remaining $40 \%$ reached dormancy. Dormancy is defined as a compensatory point of light where respiration equals photosynthesis. At this stage seedlings are stagnant and vulnerable to damage, which could be the reason why minimal damage to photosynthetic tissue $(<20 \%)$, is such an important determinant of seedling survival of $D$. oleifera (Ruiz et al. submitted), and about $8 \%$ of damage as been documented (Clark and Clark 1985). Under these circumstances, only a small fraction of seedlings would make the transition to saplings. Transition to sapling in the Nicaraguan population is a rare event $(0.77 \%)$ and might also depend on light conditions above the mean light intensity at the forest floor.

Randomness in light-gap formation seems to be key determinant in transition from seedling to sapling: Because seedlings of $D$. oleifera reached $\sim 88 \%$ of the research area the chance to recruit in a small light gap $(\sim 10 \times 10 \mathrm{~m})$ is higher than if seedlings were recruitment limited. The research questions that arise are whether light-gap formations is randomly distributed, whether these light-gaps are largely responsible for the transition from seedlings to saplings and, whether sapling is a safe stage with high transition probabilities to the next size stage. Parallel to the importance of the role of light-gaps is the idea of whether $D$. oleifera regenerates after large disturbances to the forest canopies, in which case there would be individuals regenerating at all size classes (Clark and Clark 1987). Our observations of the regeneration of $D$. oleifera suggest that the species is not dispersal limited or recruitment limited. Microsite conditions seem to play a key role in the transition to larger stages rather than catastrophic events.

Implications for current theories about tropical rainforest organization: The results presented here provide evidence that will move the current theories of recruitment and forest organization one step forward. Although there is strong evidence for the Janzen-Connell hypothesis at the seed and seedling stages; sapling recruitment seems to occur at random, which embodies the fundamental prediction of the neutral model (Hubbell 2001). In a sense, the evidence presented here suggests that the Janzen-Connell hypothesis and the Recruitment Limitation hypothesis can be detected in different life stages in a tree population.

Our main objectives here were to test hypotheses concerning recruitment dynamics and the effect of biological agents controlling the recruitment of $D$. oleifera. Specifically, we 
reject (1) the hypothesis that if seed dispersal is at random then the per sub-plot variance to mean ratio of the distribution of seeds is not different from a Poisson process. Seed were clumped distributed below the crown of the nearest conspecific tree, where seeds were damaged by the larval stage of a density responsive fly species. (2) There is some evidence in favor of the "seedling limitation hypothesis" because seedlings were clump distributed, the fraction of sub-plots receiving seedling recruitment being less than the fraction that would be received seeds if establishment were randomly distributed. About $80 \%$ of the research plot received seedling recruitment during the research period. Forty percent of the seedlings survived with $0.77 \%$ making the transition to the sapling stage. Seedling and sapling growth rates were independent of the distance to the nearest conspecific adult. There was a positive trend between slow sapling growth rate and the number of damage to sapling stems from falling branches. There is evidence to accept hypothesis 3 , if seedling insect herbivory damage decreases with the distance to the nearest conspecific adult tree of D. oleifera, then seedling survival damage will be high away from the nearest conspecific tree. These findings are consistent with key predictions embodying the natural enemy control hypothesis for seedlings, whereas sapling survival seems to be better described by a random process. We did not find evidence in favor of hypothesis 4 , if seedling relative growth rate decreases as a function of the distance to the nearest conspecific adult tree, then there is evidence suggesting a positive correlation between lower insect herbivory away from the adult $D$. oleifera and faster seedling growth rate. Seedling growth rate is a function that does not depends on the distance to the nearest conspecific adult tree. There is evidence in favor of the hypothesis that if seedling mortality is negatively related with the number of conspecific saplings, then there is evidence suggesting a positive correlation between the effect of insect herbivores and the number of saplings per sub-plot. Seedling mortality correlated with sapling density, this mortality depends on seedling insect herbivory damage.
In sum, the findings in the present study and the cumulative evidence from a series of research papers focused on a population of D. oleifera in Costa Rica, leads us to think that only seedlings that germinate in lightgaps might survive. Even when small levels of insect herbivory lead to reduced seedling longevity, and since small levels of damage seem to be omnipresent, seedling survival is highly likely to be determined by light-gap formations. Microsite conditions occurring at random can be the major force determining the transition from seedling to sapling stage.

\section{ACKNOWLEDGMENTS}

Financial support came from NSF Research in Undergraduate Institutions (RUI) grant DEB-0135350 to Douglas H. Boucher, a Block Grant from the Department of Ecology and Evolutionary Biology of the University of Michigan (UM) to Javier Ruiz (JR), an individual fellowship from the International Institute (UM) to JR, an International Foundation for Science Grant (D-3939-1) to JR and the Rackham International Student Grant of the UM to JR. John Vandermeer, Ivette Perfecto, Iñigo Granzow de la Cerda and, Beverly Rathcke provided insightful comments. One anonymous reviewer provide insightful comments. We also thanks to the research team of Proyecto Biodiversidad-URACCAN for support in many ways.

\section{RESUMEN}

Estudiamos la dinámica de regeneración de la población de Dipteryx oleifera en un bosque húmedo tropical del este de Nicaragua. Semillas y plántulas se encuentran altamente agregadas, pero la distribución de vástagos podría ser al azar. La supervivencia de plántulas aumenta con la distancia al congéner más cercano, donde la densidad de plántulas es más baja. Como las tasas de crecimiento relativo de plántulas no se correlacionan con la distancia al congénere más cercano, la supervivencia de las plantas pareciera no estar determinada por el crecimiento de plántulas. La densidad de plántulas está inversamente correlacionada con los niveles de daño de herbivoría insectívora. La supervivencia de plántulas se correlaciona negativamente con el número de vástagos, lo cuál sugiere que los insectos herbívoros 
podrían estar localizando vástagos y árboles y de allí, las plántulas. La supervivencia de plántulas presentó una distribución significativamente agrupada lejos de los congéneres más cercanos. Los parches de plántulas más grandes fueron más efímeros que los parches pequeños y aislados ubicados lejos de los árboles adultos. Los resultados coinciden con la hipótesis de Janzen-Connell sobre estados de semilla y plántula. Además, ofrecen evidencia en favor de la hipótesis de Limitación de Reclutamiento para los vástagos, ya que los vástagos podrían estar estableciéndose en claros de luz pequeños que se forman al azar.

Palabras claves: Dipteryx oleifera, Dipteryx panamensis, limitación de reclutamiento, hipótesis de Janzen-Connell, semillas, plántulas, vástagos, Nicaragua.

\section{REFERENCES}

Baddeley, A. 2006. The spatstat Package: Spatial Point Pattern analysis, model-fitting, simulation, tests. (Downloaded: July 25, 2008, www.spatstat.org).

Blundell, A.G. \& D.R. Peart. 1998. Distance-dependence in herbivory and foliar condition for juvenile Shorea trees in Bornean dipterocarp rain forest. Oecologia 117:151-160.

Bonaccorso, F. J., W. E. Glanz \& C. M. Sandford. 1980. Feeding assemblages of mammals at fruiting Dipteryx panamensis (Papilionaceae) trees in Panama: seed predation, dispersal, and parasitism. Rev. Biol. Trop. 28: 61-72.

Bradford, D.F. \& C.C. Smith. 1977. Seed predation and seed number in Scheelea palm fruits. Ecology 58: 667-673.

Clark, D. A. \& D. B. Clark. 1984. Spacing dynamics of a tropical rain forest tree: evaluation of the Janzen-Connel model. The American Naturalist 124: 769-788.

Clark, D. B. \& D. A. Clark. 1985. Seedling dynamics of a tropical tree: impacts of herbivory and meristem damage. Ecology 66: 1884-1892.

Clark, D.B. \& D.A. Clark. 1987. Population ecology and microhabitat distribution of Dipteryx panamensis a neotropical rain forest tree. Biotropica 19: 236-244.

Clark, D.B. \& D.A. Clark. 1991. The impact of physical damage on canopy tree regeneration in tropical rain forest. J. Ecol. 79: 447-457.

Clark, D.A. \& D.B. Clark. 1992. Life history diversity of canopy and emergent trees in a neotropical rain forest. Ecological Monographs 62: 315-344.

Clark, J.S., B. Beckage, P. Camill, B. Cleveland, J. HilleRisLambers, J. Lichter, J. McLachlan, J. Mohan
\& P.Wyckoff. 1999a. Interpreting recruitment limitation in forests. American J. Bot. 86: 1-16.

Clark, J.S., E. Macklin \& L. Wood. 1998. Stages and spatial scale of recruitment limitation in southern Appalachian forests. Ecological Monographs 68: 213-235.

Clark, J.S., M.R. Silman, R. Kern, E. Macklin \& J. HilleRis-Lambers. 1999b. Seed dispersal near and far: patterns across temperate and tropical forests. Ecology 80: 1475-1494.

Condit, R., P.S. Ashton, P. Baker, S. Bunyavejchewin, S. Gunatilleke, N. Gunatilleke, S.P. Hubbell, R.B.Foster, A. Itoh, J.V. LaFrankie, H.S Lee, E. Losos, N. Manokaran, R. Sukumar \& T. Yamakura. 2000. Spatial patterns in the distribution of tropical tree species. Science 288: 414-1418.

Condit R., S.P. Hubbell \& R.B. Foster. 1992. Recruitment near conspecific adults and the maintenance of tree and shrub diversity in a neotropical forest. The American Naturalist 140: 261-286.

Connell, J.H. 1971. On the roles of natural enemies in preventing competitive exclusion in some marine animals and in rain forest, p. 298-312. In P. J. Den Boer \& G. R. Grandwell (eds.). Proceedings of the Advanced Study Institute on Dynamics of Numbers in Population. Oosterbeek, Wageningen, Holland.

Dalling, J.W. \& S.P. Hubbell. 2002. Seed size, growth rate and gap microsite conditions as determinants of recruitment success for pioneer species. J. Ecol. 90: 557-568.

Dalling, J.W., H.C. Muller-Landau, S.J. Wright \& S.P. Hubbell. 2002. Role of dispersal in the recruitment limitation of neotropical pioneer species. J. Ecol. 90: 714-727.

Forget, P.-M. 1992. Seed removal and seed fate in Gustavia superba (Lecythidaceae). Biotropica 24: 408-414.

Forget, P.-M. 1993. Post-dispersal predation and scatterhoarding of Dipteryx oleifera (Papilionacea) seeds by rodents in Panama. Oecologia 94: 255-261.

Forget, P.-M. \& D. Wenny. 2005. How to elucidate seed fate? a review of methods used to study seed removal and secondary seed dispersal, p. 379-393. In P.-M. Forget, J. E. Lambert, P. E. Hulme \& S. B. Vander Wall (eds.). Seed fate predation, dispersal and seedling establishment. CABI Publishing. 
Forget, P. M. \& T. Milleron. 1991. Evidence for secondary seed dispersal by rodents in Panama. Oecologia 87: 596-599.

Granzow-de-la-Cerda, I., N. Zamora, J.H. Vandermeer \& D.H. Boucher. 1997. Biodiversidad de especies arbóreas en el bosque tropical húmedo del Caribe Nicaragüense siete años después del huracán Juana. Rev. Biol. Trop. 45:1409-1419.

Howe, H.F. \& J. Smallwood. 1982. Ecology of seed dispersal. Ann. Rev. Ecol. Syst. 13: 201-228.

Hubbell, S.P. 2001. The Unified Neutral Theory of Biodiversity and Biogeography. Monographs in Population Biology 32. Princeton, Princeton, New Jersey, USA.

Hurtt, G.C. \& S.W. Pacala. 1995. The consequences of recruitment limitation: reconciling chance, history and competitive differences between plants. J. Theoretical Biol. 176: 1-12.

Hyatt, L.A., M.S. Rosenberg, T.G. Howard, G. Bole, W. Fang, K. Anastacia, K. Brown, R. Grella, K. Hinman, J.P. Kruidiziel \& J. Gurevitch. 2003. The distance dependence prediction of the Janzen-Connell hypothesis: a meta-analysis. Oikos 103: 590-602.

Janzen, D.H.1970. Herbivores and the number of tree species in tropical forest. The American Natrualist 104: 501-528.
Muller-Landau, H.C., J. Wright, O. Calderon, S.P. Hubbell \& R.B. Foster. 2002. Assessing recruitment limitation: concepts, methods and case study from a tropical forest, p. 35-52. In D.J. Levey, W.R. Silva and M. Galetti (eds). Seed Dispersal and Frugivory: Ecology, Evolution and Conservation. CAB International.

Nathan. R. \& H.C. Muller-Landau. 2000. Spatial patterns of seed dispersal their determinants and consequences for recruitment. Trends Ecol. Evol. 15:278-285.

Ribbens E, J.A. Silander \& S.W. Pacala.1994. Seedling recruitment in forests: calibrating models to predict patterns of tree seedling dispersion. Ecology 75: 1794-1806

Tilman, D. 1994. Competition and biodiversity in spatially structured habitats. Ecology 75: 2-16.

Vandermeer, J. \& D.E. Goldberg. 2003. Population Ecology: First Principles. Princeton, Princeton, New Jersey, USA.

Wilson, D.E. \& D.H. Janzen. 1972. Predation on Scheelea palm seeds by Bruchid beetles: seed density and distance from the parent palm. Ecology 53: 954-959.

Wright, S.J. 1983. The dispersion of eggs by a Bruchid beetle among Scheelea palm seeds and the effect of distance to the parent palm. Ecology 64: 1016-1021.

Zar, J.H. 1999. Biostatistical Analysis. Prentice-Hall. New Jersey, USA. 